TITLE:

\title{
Increase in thermal stability of Moloney murine leukaemia virus reverse transcriptase by site- directed mutagenesis.
}

\section{$\operatorname{AUTHOR(S):~}$}

Yasukawa, Kiyoshi; Mizuno, Masaki; Konishi, Atsushi; Inouye, Kuniyo

\section{CITATION:}

Yasukawa, Kiyoshi ...[et al]. Increase in thermal stability of Moloney murine leukaemia virus reverse transcriptase by site-directed mutagenesis.. Journal of biotechnology 2010, 150(3): 299-306

\section{ISSUE DATE:}

2010-11

URL:

http://hdl.handle.net/2433/131848

\section{RIGHT:}

(c) 2010 Elsevier B.V.; この論文は出版社版でありません。引用の際には 出版社版をご確認ご利用ください。; This is not the published version. Please cite only the published version. 
Journal of Biotechnology

Increase in Thermal Stability of Moloney Murine Leukaemia Virus Reverse Transcriptase by Site-directed Mutagenesis

Kiyoshi Yasukawa , Masaki Mizuno, Atsushi Konishi, Kuniyo Inouye

Division of Food Science and Biotechnology, Graduate School of Agriculture,

Kyoto University, Sakyo-ku, Kyoto 606-8502, Japan

Key words: cDNA synthesis; Moloney murine leukaemia virus; reverse transcriptase; site-directed mutagenesis; stability

Abbreviations: AMV, avian myeloblastosis virus; MMLV, Moloney murine leukaemia virus; RT, reverse transcriptase; T/P, template-primer; TCA, trichloroacetic acid

*Corresponding author. Tel: +81-75-753-6267, Fax: +81-75-753-6265, E-mail address: yasukawa@kais.kyoto-u.ac.jp 


\section{Abstract}

We hypothesized that the thermal stability of Moloney murine leukaemia virus reverse transcriptase (MMLV RT) will increase with increases in its ability to bind with a template-primer (T/P). To test this hypothesis, we introduced positive charges into MMLV RT by site-directed mutagensis at positions that have been implicated in the interaction with T/P. Thirty-six variants were constructed in which one of twelve residues (Glu69, Gln84, Asp108, Asp114, Glu117, Glu123, Asp124, Glu286, Glu302, Trp313, Leu435, and Asn454) was replaced with Lys, Arg, or Ala, and these were expressed in Escherichia coli. In about half of these 36 variants, thermal inactivation at $50^{\circ} \mathrm{C}$ was reduced in the presence of the $\mathrm{T} / \mathrm{P}$, which suggested that this strategy was effective at stabilizing MMLV RT. We next combined three of the 36 mutations, Glu286 $\rightarrow$ Ala, Glu302 $\rightarrow$ Lys, and Leu435 $\rightarrow$ Arg, and the mutation, Asp524 $\rightarrow$ Ala, which is known to abolish the RNase $\mathrm{H}$ activity and increase the stability. Temperatures of 54 and $56^{\circ} \mathrm{C}$ reduced the initial reverse transcription activity by $50 \%$ over a 10-min incubation in the triple variant $\mathrm{E} 286 \mathrm{R} / \mathrm{E} 302 \mathrm{~K} / \mathrm{L} 435 \mathrm{R}$ and quadruple variant E286R/E302K/L435R/D524A, respectively. These temperatures were higher than that observed for WT $\left(45^{\circ} \mathrm{C}\right)$. The highest temperatures at which the triple and quadruple variants exhibited cDNA synthesis activity were $60^{\circ} \mathrm{C}$, which was again higher than for WT $\left(54^{\circ} \mathrm{C}\right)$. Thus, highly stable MMLV RT variants were generated by this mutation strategy.

Key words: cDNA synthesis; Moloney murine leukaemia virus; reverse transcriptase; site-directed mutagenesis; stability. 


\section{Introduction}

Reverse transcriptase (RT) [EC 2.7.7.49], the enzyme responsible for viral genome replication, possesses RNA- and DNA-dependent DNA polymerase as well as RNase H activities (Temin and Mizutani, 1975; Baltimore, 1975). Due to their high catalytic activity and fidelity (Roberts et al., 1988), RTs from Moloney murine leukaemia virus (MMLV) and avian myeloblastosis virus (AMV) are the most extensively used in conventional cDNA synthesis (Kimmel and Berger, 1987). They are also used in RNA-specific amplification, which is an isothermal reaction $\left(41-43^{\circ} \mathrm{C}\right)$ that specifically amplifies a target RNA sequence, with RNA polymerase (Kievits et al., 1991; Ishiguro et al., 2003). The MMLV RT is a 75-kDa monomer, whereas AMV RT is a heterodimer consisting of a $63-\mathrm{kDa} \alpha$ subunit and a $95-\mathrm{kDa} \beta$ subunit. Structurally, MMLV RT is comprised of the fingers, palm, thumb, connection, and RNase H domains (Georgiadis et al., 1995; Das and Georgiadis., 2004; Lim et al., 2006; Cote et al., 2008). This nomenclature, which was originally used in HIV-1 RT (Khlstaedt et al., 1992), is based on the resemblance to a right hand. The $\alpha$ subunit of AMV RT is also comprised of these five domains, while the $\beta$ subunit consists of these five domains as well as the C-terminal integrase domain (Bieth and Darlix, 1991). The active site of the DNA polymerase reaction resides in the fingers/palm/thumb domain, while that of RNase $\mathrm{H}$ reaction lies in the $\mathrm{RNase} \mathrm{H}$ domain.

Thermal stability of DNA polymerases is important for their wide-range practical use. For cDNA synthesis and RNA-specific amplification procedures, an elevated reaction temperature is highly desirable because it reduces RNA secondary structure and nonspecific binding of the primer. Thermostable DNA-dependent DNA polymerases that are currently used in the polymerase chain reaction (PCR), such as the one isolated from Thermus 
aquaticus (Taq) (Chien et al., 1976), retain activity even after the incubation at $>90^{\circ} \mathrm{C}$. However, unlike DNA polymerases, RT activity is not thermally stable. For example, the initial reverse transcription activities of MMLV RT and AMV RT are reduced by $50 \%$ at 44 and $47^{\circ} \mathrm{C}$, respectively, during a 10-min incubation (Yasukawa et al., 2008). Thermal stability of RT has been markedly improved by eliminating its RNase $\mathrm{H}$ activity (Berger et al., 1983; Gerard et al., 2002), resulting in an increase in reaction temperature from $37^{\circ} \mathrm{C}$ to higher than $42^{\circ} \mathrm{C}$ (Aresi and Hogrefe, 2009). However, RNase H-minus RT cannot be used in an RNA-specific amplification reaction because this procedure requires both DNA polymerase and RNase $\mathrm{H}$ activities. Therefore, the RNA-specific amplification reaction must still be performed at low temperatures around 41 to $43^{\circ} \mathrm{C}$ (Masuda et al., 2004; Yasukawa et al., 2010a). Considering that RNA is stable up to $65^{\circ} \mathrm{C}$, further stabilization of RT would be desirable for cDNA synthesis. Improvement in the thermal stabilities of AMV RT and MMLV RT is therefore still an important goal.

The purpose of the present study was to increase the thermal stability of MMLV RT. We hypothesized that the thermal stability will increase if the binding ability of MMLV RT toward the template-primer $(\mathrm{T} / \mathrm{P})$ could be increased. Based on this hypothesis, we introduced positive charges into MMLV RT by site-directed mutagenesis at positions that have been implicated in the interaction with $\mathrm{T} / \mathrm{P}$. Two highly stable variants, E286R/E302K/L435R and E286R/E302K/L435R/D524A, were generated.

\section{Materials and methods}

\subsection{Materials}


$\mathrm{p}(\mathrm{dT})_{15}$ was purchased from Life Technologies Japan Ltd. (Tokyo, Japan). [methyl- $\left.{ }^{3} \mathrm{H}\right] \mathrm{dTTP}(1.52 \mathrm{TBq} / \mathrm{mmol})$ and poly $(\mathrm{rA})$ were purchased from GE Healthcare (Buckinghamshire, UK). The glass filter GF/C $2.5 \mathrm{~cm}$ is a product of Whatman (Middlesex, UK). RT concentration was determined as according to the method of Bradford (Bradford, 1976) using Protein Assay CBB Solution (Nacalai Tesque, Kyoto, Japan) with bovine serum albumin (Nacalai Tesque) as a standard. Standard RNA, which was an RNA of 1014-nucleotides corresponding to DNA sequence 8353-9366 of the cesA gene of Bacillus cereus (GenBank accession number DQ360825), was prepared by in vitro transcription. (Yasukawa et al., 2010a).

\subsection{Bacterial strains, plasmids and transformation}

E. coli BL21(DE3) [F, ompT, $h s d S_{B}\left(r_{B}^{-} m_{B}^{-}\right)$gal dcm (DE3)] cells were used. pET-MRT is an expression plasmid for the wild-type MMLV (Yasukawa et al., 2008, 2009). Site-directed mutagenesis was carried out using a Quikchange ${ }^{\mathrm{TM}}$ site-directed mutagenesis kit (Stratagene, La Jolla, CA). The nucleotide sequences of mutated MMLV RT genes were verified by a Shimadzu DNA sequencer DSQ-2000 (Kyoto, Japan). BL21(DE3) cells were transformed with each of the resulted plasmids and cultured in L broth. Ampicillin was used at the concentration of $50 \mu \mathrm{g} / \mathrm{ml}$.

\subsection{Expression and purification of $M M L V R T$}

Three $\mathrm{ml}$ of L broth containing $50 \mu \mathrm{g} \mathrm{ml}^{-1}$ ampicillin was inoculated with the glycerol stock of the transformed BL21(DE3) and incubated for $16 \mathrm{~h}$ with shaking at $30^{\circ} \mathrm{C}$. The 
expression of the RT gene was induced by the autoinduction system (Novagen, Darmstadt, Germany). MMLV RT was purified from culture medium using HisLink Spin Protein Purification System (Promega, Madison, WI). Briefly, the bacterial cells were disrupted by FastBreak Cell Lysis Reagent, followed by addition of HisLink Protein Purification Resin to the culture. The samples were then transferred to HisLink Spin Column where unbound protein was washed away. MMLV RT was recovered by the elution with $0.2 \mathrm{ml}$ of $100 \mathrm{mM}$ HEPES-NaOH (pH 7.5), $500 \mathrm{mM}$ imidazole. To the eluted solution, $80 \%$ saturated ammonium sulfate solution was added for a final concentration to be $40 \%$ saturation. After centrifugation $(20,000 \times \mathrm{g}, 20 \mathrm{~min})$, the precipitate was dissolved in $0.5 \mathrm{mM}$ HEPES-NaOH $(\mathrm{pH} 7.5)$ and then dialyzed against $20 \mathrm{mM}$ potassium phosphate ( $\mathrm{pH} 7.2$ ), $2 \mathrm{mM}$ DTT, $0.2 \%$ Triton X-100, 50\% glycerol. MMLV RT thus purified was stored at $-80^{\circ} \mathrm{C}$ before use.

\subsection{SDS-PAGE}

SDS-PAGE was performed in a $10 \%$ polyacrylamide gel under reducing conditions according to the method of Laemmli (Laemmli, 1970). Proteins were reduced by treatment with $2.5 \%$ of 2 -mercaptoethanol at $100^{\circ} \mathrm{C}$ for $10 \mathrm{~min}$, and then applied onto the gel. A constant current of $40 \mathrm{~mA}$ was applied for $40 \mathrm{~min}$. After electrophoresis, proteins were stained with Coomassie Brilliant Blue R-250. The molecular mass marker kit consisting of rabbit muscle phosphorylase $\mathrm{B}(97.2 \mathrm{kDa})$, bovine serum albumin $(66.4 \mathrm{kDa})$, hen egg white ovalbumin $(44.3 \mathrm{kDa})$, and bovine carbonic anhydrase $(29.0 \mathrm{kDa})$ was a product of Takara Bio Inc (Otsu, Japan). 
The reaction was carried out in $25 \mathrm{mM}$ Tris- $\mathrm{HCl}(\mathrm{pH} 8.3), 50 \mathrm{mM} \mathrm{KCl}, 2 \mathrm{mM}$ DTT, 5 $\mathrm{mM} \mathrm{MgCl} 2,12.5 \mu \mathrm{M}$ poly(rA)-p(dT) ${ }_{15}$ (this concentration is expressed based on $\mathrm{p}(\mathrm{dT})_{15}$ ), $0.2 \mathrm{mM}\left[{ }^{3} \mathrm{H}\right] \mathrm{dTTP}(1.85 \mathrm{~Bq} / \mathrm{pmol})$, and 5-10 nM MMLV RT at $37^{\circ} \mathrm{C}$. An aliquot $(20 \mu \mathrm{l})$ was taken from the reaction mixture at a specified time and immediately spotted onto the glass filter. Unincorporated $\left[{ }^{3} \mathrm{H}\right] \mathrm{dTTP}$ was removed by three washes of chilled $5 \%(\mathrm{w} / \mathrm{v})$ trichloroacetic acid (TCA) for 10 min each, followed by one wash of chilled $95 \%$ ethanol. The radioactivity retained on the dried filters was counted in $2.5 \mathrm{ml}$ of Ecoscint $\mathrm{H}$ (National Diagnostics, Yorkshire, UK). The initial reaction rate was estimated from the time-course for incorporation of $\left[{ }^{3} \mathrm{H}\right] \mathrm{dTTP}$. The kinetic parameters, $k_{\text {cat }}$ and $K_{\mathrm{m}}$, were determined with Kaleida Graph Version 3.5 (Synergy Software, Essex, VT), based on the Michaelis-Menten equation and using the non-linear least-squares regression method (Sakoda and Hiromi, 1976).

\subsection{Irreversible thermal inactivation of $M M L V R T$}

MMLV RT (100 nM) in $10 \mathrm{mM}$ potassium phosphate (pH 7.6), $2 \mathrm{mM}$ DTT, 0.2\%(v/v) Triton $\mathrm{X}-100,10 \%(\mathrm{v} / \mathrm{v})$ glycerol was incubated in the presence of $28 \mu \mathrm{M}$ poly(rA)-p(dT) $)_{15}$ at $50^{\circ} \mathrm{C}$ for $15 \mathrm{~min}$ followed by the incubation on ice for $30-60 \mathrm{~min}$. The remaining activity of the RT toward the incorporation of dTTP into poly(rA)-p(dT) ${ }_{15}$ was determined at $37^{\circ} \mathrm{C}$ as described above.

\subsection{Thermodynamic analysis of irreversible thermal inactivation}


Assuming that the thermal inactivation reaction of RT is irreversible and consists of only one step, the first-order rate constant, $k_{\mathrm{obs}}$, of the thermal inactivation was evaluated by plotting logarithmic values of the residual activity against the time of heat treatment according to Eq. 1.

$$
\ln B=A-k_{\text {obs }} t
$$

where $A$ is the constant term, and $B$ is the relative activity (\%) defined as the ratio of the initial reaction rate at a time for the thermal incubation $(=t)$ to that without the incubation. The activation energy, $E_{\mathrm{a}}$, for the thermal inactivation was determined from an Arrhenius plot according to Eq. 2.

$$
\ln \left(k_{\mathrm{obs}}\right)=A-\left(E_{\mathrm{a}} / R\right)(1 / T)
$$

where $A, R$, and $T$ are the constant term, the gas constant $\left(=8.314 \mathrm{~J} \mathrm{~K}^{-1} \mathrm{~mol}^{-1}\right)$, and absolute temperature in degrees Kelvin. $T_{50}$ was estimated by Arrhenius plot as the temperature at which the $k_{\mathrm{obs}}$ value gives the remaining activity of $50 \%$ at 10 min according to Eq. 1 .

\subsection{Measurement of the RT activity for cDNA synthesis}

The reaction mixture $(20 \mu \mathrm{l})$ was prepared by mixing water $(12 \mu \mathrm{l}), 10 \times \mathrm{RT}$ buffer $[250$ mM Tris-HCl (pH 8.3), $500 \mathrm{mM} \mathrm{KCl,} 20 \mathrm{mM}$ DTT] $(2 \mu \mathrm{l}), 2.0 \mathrm{mM}$ dNTP $(1 \mu \mathrm{l}), 10 \mu \mathrm{M}$ RV-R26 primer $(1 \mu \mathrm{l}), 1.6 \mathrm{pg} / \mu \mathrm{l}$ standard RNA $(1 \mu \mathrm{l}), 1.0 \mu \mathrm{g} / \mu \mathrm{l}$ E. coli RNA $(1 \mu \mathrm{l})$, and 100 $\mathrm{nM}$ MMLV RT [2 $\mu \mathrm{l}$ in $10 \mathrm{mM}$ potassium phosphate (pH 7.6), $2 \mathrm{mM}$ DTT, $0.2 \%(\mathrm{v} / \mathrm{v})$ 
Triton X-100, and $10 \%(\mathrm{v} / \mathrm{v})$ glycerol] in a PCR tube. The reaction was run at a range of temperatures from $46-64^{\circ} \mathrm{C}$ for $30 \mathrm{~min}$ and stopped by heating at $95^{\circ} \mathrm{C}$ for $5 \mathrm{~min}$. The PCR reaction mixture $(30 \mu \mathrm{l})$ was then prepared by mixing water $(18 \mu \mathrm{l})$, the product of the reverse transcription reaction $(3 \mu \mathrm{l}), 10 \times \mathrm{PCR}$ buffer $[500 \mathrm{mM} \mathrm{KCl}, 100 \mathrm{mM}$ Tris- $\mathrm{HCl}(\mathrm{pH}$ 8.3), $15 \mathrm{mM} \mathrm{MgCl}](3 \mu \mathrm{l}), 10 \mu \mathrm{M}$ F5 primer $(1 \mu \mathrm{l})$, of $10 \mu \mathrm{M}$ RV primer $(1 \mu \mathrm{l}), 2.0 \mathrm{mM}$ dNTP $(3 \mu \mathrm{l})$, and $1 \mathrm{U} / \mu \mathrm{l}$ recombinant Taq polymerase $(1 \mu \mathrm{l})$ (Toyobo, Osaka, Japan). The cycling parameters were $95^{\circ} \mathrm{C}$ for $30 \mathrm{~s}$, followed by 30 cycles at $95^{\circ} \mathrm{C}$ for $30 \mathrm{~s}, 55^{\circ} \mathrm{C}$ for $30 \mathrm{~s}$, and $72^{\circ} \mathrm{C}$ for $30 \mathrm{~s}$. The amplified products were separated on $1.0 \%$ agarose gels and stained with ethidium bromide $(1 \mu \mathrm{g} / \mathrm{ml})$. The nucleotide sequences of the primers are shown in Table 1.

\section{Results}

\subsection{Design of mutations}

Our strategy for increasing the thermal stability of MMLV RT was to increase its binding ability toward the template-primer $(\mathrm{T} / \mathrm{P})$ by introducing positive charges into MMLV RT by site-directed mutagenesis at the positions that have previously been implicated in the interaction with $\mathrm{T} / \mathrm{P}$. The $\mathrm{T} / \mathrm{P}$ has phosphate groups and is negatively charged. Based on the crystal structure of the fingers, palm, thumb, and connection domains (Thr24-Pro474) of MMLV RT (Das and Georgiadis, 2004), we selected the following 12 residues to be mutated. In the fingers domain (i.e., Thr24-Asp124 and Phe156-Ser195), polypeptide regions Ser60-Gln84, Asn95-Asp124, Phe156-Cys157, and Gln190-Asn194 are located at the surface which interacts with T/P. We thus selected six negatively charged 
residues (Glu69, Asp108, Asp114 Glu117, Glu123, and Asp124). We also selected Gln84 because site-directed mutagenesis study has identified that Gln84 interacted with T/P (Liu et al., 2006). In the palm domain (i.e., Ile125-Phe155 and Pro196-Glu275), polypeptide regions Ile125-Phe155, Leu220-Glu233, and Lys257-Glu275 are located at the surface which interacts with T/P. However, we did not select any residues because this domain contains the catalytically important residues, Asp224 and Asp225, and mutation might affect their geometries. In the thumb domain (i.e., Gly276-Leu359), residues in polypeptide regions Leu280-Thr287, Arg301-Leu333, and Ala354-Leu359 are located at the surface which interacts with T/P. We selected two negatively charged residues (Glu286 and Glu302). We also selected Trp313 because random mutagenesis studies have identified the mutation Trp313 $\rightarrow$ Phe to increase the stability of MMLV RT (Arezi and Hogrefe, 2009). In the connection domain (i.e., Pro360-Asp468), polypeptide regions Pro360-Lys373, Tyr394-Ala436, and Ser453-Ala462 are located at the surface which interacts with T/P. We selected two residues (Leu435 and Asn454) because random mutagenesis studies have identified the mutations Leu435 $\rightarrow$ Gly, and Asn454 $\rightarrow$ Met to increase the stability of MMLV RT (Arezi and Hogrefe, 2009), while that of Leu435 $\rightarrow$ Lys was identified as improving the solubility of MMLV RT (Das and Geordiadis, 2001). Figure 1 shows the locations of these 12 residues in MMLV RT. Each of these was changed either to one of the two positively charged amino acids (Lys and Arg) or to an uncharged one (Ala).

\subsection{Activities and stabilities of single MMLVRT variants}

The 36 variants were expressed in E. coli and purified. An RNase H activity-deficient and a stable variant D524A (Gerard et al., 2002; Mizuno et al., 2010) were also prepared. 
Following SDS-PAGE under reducing conditions, purified WT and variants yielded a single band with a molecular mass of $75 \mathrm{kDa}$ (Figs. 2A-C). The yields of the purified enzymes from $0.7 \mathrm{ml}$ of culture were in the range of $20-74 \mu \mathrm{g}$, which were comparable to that of the WT $(56 \mu \mathrm{g})$. UV absorption spectra of the purified enzymes exhibited the typical UV absorption spectrum of purified protein with a deep trough at about $250 \mathrm{~nm}$ and a peak at $275 \mathrm{~nm}$ (data not shown). The ratios of the absorbance at $280 \mathrm{~nm}\left(A_{280}\right)$ to $A_{260}$ of the purified enzymes were in the range of 1.8 to 1.9 , indicating that they hardly contained nucleic acids.

Table 2 shows the specific activities of the reverse transcription reaction for the WT, D524A, and the 36 variants. The specific activity of WT was 70,000 units/mg. All variants can be classified into three groups: (1) The specific activity of D114R was zero; (2) The specific activities of D108K, D108R, D114K, W313K, and W313R were 10-20\% of that of WT; and (3) The specific activities of the other 30 variants and D524A were $40-120 \%$ of that of WT.

Table 2 also shows the initial reaction rates before and after heat treatment of the WT, D524A, and all single variants (except for the inactive D114R). Relative activity was defined as the ratio of the initial reaction rate for a $15-\mathrm{min}$ incubation at $50^{\circ} \mathrm{C}$ in the presence of $\mathrm{T} / \mathrm{P}$ to the rate without incubation. The relative activities of WT and D524A were 1.4 and $14 \%$, respectively, which agreed well with those reported in our previous studies (Yasukawa et al., 2008; Mizuno et al., 2010). The relative activity of Q84K was zero, indicating that Q84K was less stable than the WT. The relative activities of the 18 variants (E69A, E69R, D108A, D108K, D108R, E117A, D124K, D124R, E286A, E286K, E286R, E302A, E302K, W313K, W313R, L435A, L435R, and N454R) were in the range of 6-24\%, which was substantially higher than that of WT (1.4\%). Of these 18, E302K exhibited the 
highest relative activity (24\%), followed by six other variants (E69R, D124K, D124R, E286K, E286R, and L435R) (13-18\%).

\subsection{Activities and stabilities of multiple variants of $M M L V R T$}

To generate highly stable MMLV RT variants, we selected Glu286 $\rightarrow$ Arg, Glu302 $\rightarrow$ Lys, and Leu435 $\rightarrow$ Arg as the mutations to be combined. Glu69 $\rightarrow$ Arg, Asp124 $\rightarrow$ Lys, and Asp124 $\rightarrow$ Arg were not chosen because they decreased the specific activity to 77,66 , and $64 \%$, respectively, of that of WT (Table 2). The RNase H activity-eliminating and stabilizing mutation, Asp524 $\rightarrow$ Ala, was also included in the combination. The resulting triple variant E286R/E302K/L435R and the quadruple variant E286R/E302K/L435R/D524A were expressed in E. coli and purified. Upon SDS-PAGE under reducing conditions, purified variants yielded a single band with a molecular mass of $75 \mathrm{kDa}$ (Fig. 2D). From $200 \mathrm{ml}$ of cultures, we obtained yields of purified triple and quadruple variant proteins of 410 and 390 $\mu \mathrm{g}$, respectively.

Table 3 shows the activities and stabilities of the triple and quintuple variant proteins. Their specific activities were $70 \%$ of that of WT. Their relative activities after the thermal incubation treatment at $50^{\circ} \mathrm{C}$ for 15 min were higher than those of WT and D524A, both in the absence and presence of the $\mathrm{T} / \mathrm{P}$, indicating that these variant proteins were more stable than the WT and D524A.

\subsection{Steady-state kinetic analysis}

Figure 3 shows the initial reaction rates for $5 \mathrm{nM}$ RT at various $\mathrm{T} / \mathrm{P}$ concentrations 
$(0-25 \mu \mathrm{M})$ at $37^{\circ} \mathrm{C}$. A saturation profile was obtained for Michaelis-Menten kinetics, and the $K_{\mathrm{m}}$ and $k_{\text {cat }}$ values were separately determined (Table 4 ). The $K_{\mathrm{m}}$ values of the triple and quadruple variants were 30 and $40 \%$ of that of WT, respectively, while their $k_{\text {cat }}$ values were 40 and $50 \%$ of that of WT, respectively. The $k_{\text {cat }} / K_{\mathrm{m}}$ values of the triple and quadruple variants were 170 and $130 \%$ of that of WT.

\subsection{Irreversible thermal inactivation of $R T$}

The remaining reverse transcription activities of WT and the variants were determined at $37^{\circ} \mathrm{C}$ after thermal treatment in the presence of the T/P. The WT and D524A RTs were treated at $48-52^{\circ} \mathrm{C}$, while the multiple variant $\mathrm{RTs}$ were treated at $52-58^{\circ} \mathrm{C}$. The natural logarithm of the remaining activity plotted against the incubation time gave linear relationships at $52^{\circ} \mathrm{C}$ (Fig. $4 \mathrm{~A}$ ) and at all other temperatures examined (data not shown), indicating that the inactivation followed pseudo-first-order kinetics. The relative activity of WT decreased to less than $10 \%$ at 5 min. The relative activity of D524A decreased more slowly than did WT, but decreased to $20 \%$ at $5 \mathrm{~min}$. The relative activities of the triple and quadruple variants decreased only slightly, indicating that they were much more stable than WT and D524A.

Figure 4B shows an Arrhenius plot of $k_{\mathrm{obs}}$ of the thermal inactivation of RT in the presence of the T/P. The natural logarithm of $k_{\text {obs }}$ and $1 / T$ showed a linear relationship. The temperatures required to reduce initial activity by $50 \%$ over a 10 -min incubation $\left(T_{50}\right)$ were $45,48,54$, and $56^{\circ} \mathrm{C}$ for the $\mathrm{WT}, \mathrm{D} 524 \mathrm{~A}$, the triple variant, and the quadruple variant, respectively, as estimated from the Arrhenius plot, indicating that the stabilities were in the order of the quadruple variant $>$ the triple variant $>$ D524A $>$ WT. The activation energies 
$\left(E_{\mathrm{a}}\right)$ of thermal inactivation of WT, D524A, the triple variant, and the quadruple variant, as calculated from the slope, showed a close similarity at $241 \pm 46,279 \pm 15,298 \pm 42$, and $322 \pm 22 \mathrm{~kJ} \mathrm{~mol}^{-1}$, respectively.

\subsection{RT-catalyzed cDNA synthesis}

The cDNA synthesis reaction was carried out with WT and the variants at $44-64^{\circ} \mathrm{C}$. The reaction product was subjected to PCR, followed by agarose gel electrophoresis, to determine the rate of cDNA synthesis at specific temperatures (Fig. 5). The highest temperatures at which cDNA synthesis occurred were $54,56,60$, and $60^{\circ} \mathrm{C}$, for the WT, D524A, the triple variant, and the quadruple variant, respectively. This indicated stability in the order of the triple and quadruple variants $>$ D524A $>$ WT.

\section{Discussion}

4.1. Stability of MMLV RT following introduction of positive charges by site-directed mutagenesis

Our hypothesis that the thermal stability of MMLV RT increases when binding ability for the template-primer $(\mathrm{T} / \mathrm{P})$ increases is based on the evidence that $\mathrm{T} / \mathrm{P}$ increases the thermal stabilities of MMLV RT and AMV RT (Gerard et al., 2002; Yasukawa et al., 2008). A number of variants exhibited higher stability than WT (Table 2); some exhibited even higher stability than D524A, a known stable variant. Therefore, our strategy appeared to be effective for stabilizing MMLV RT. However, mutations at Asp108 or Asp114 decreased the 
activity, while those at Gln84 decreased the stability. In the fingers domain of MMLV RT (i.e., Thr24-Asp124 and Phe156-Ser195), the Lys103, Arg110, and Arg116 are conserved in HIV-1 RT, AMV RT, and the Klenow fragment, and are thought to provide the binding site for T/P (Chowdhury et al., 1996). We speculate that mutations at Gln84, Asp108, or Asp114 affected the geometries of the regions around Lys103, Arg110, or Arg116, resulting in decreased activity or stability.

\subsection{Affinity of MMLV RT for T/P following introduction of positive charges by site-directed} mutagenesis

The relative activities of the triple (E286R/E302K/L435R) and quadruple (E286R/E302K/L435R/D524A) variants were higher in the presence of $\mathrm{T} / \mathrm{P}$ than in its absence (Table 3). The $K_{\mathrm{m}}$ values for T/P of the triple and quadruple variants were $20-30 \%$ of that of WT (Table 4). Thus, the affinities of the triple and quadruple variants for T/P were apparently higher than WT affinity. However, even in the absence of the T/P, the relative activities of the triple and quadruple variants were higher than that of WT (Table 3). This suggests that the increased stability of the triple and quadruple variants resulted from an increased affinity for $\mathrm{T} / \mathrm{P}$ and also an increased intrinsic stability.

It was recently reported that five stabilizing mutations (Glu69 $\rightarrow$ Lys, Glu302 $\rightarrow$ Arg, Trp313 $\rightarrow$ Phe, Leu435 $\rightarrow$ Gly, and Asn454 $\rightarrow$ Lys) were developed by random mutagenesis, and that a highly stable multiple variant E69K/E302R/W313F/L435G/N454K (M5) was generated (Arezi and Hogrefe, 2009). Some of the substituted residues in M5 (Glu302 and Leu435) are overlapped with the triple and quadruple variants presented in this study. Interestingly, M5 was stabilized in the presence of the T/P, but not in its absence (Arezi and 
Hogrefe, 2009). This suggests that unlike the triple and quadruple variants, the increased stability of M5 resulted from an increased affinity for $\mathrm{T} / \mathrm{P}$, but not from an increased intrinsic stability. We speculate that the mechanism of stabilization of M5 is different from that of the triple and quadruple variants, although both in M5 and the triple and quadruple variants, the number of negatively charged residues (Asp and Glu) decreased by two, and the number of positively charged residues (Lys and Arg) increased by three compared to WT.

4.3. Stability of $M M L V R T$ by the combined stabilizing mutations, Glu286 $\rightarrow$ Arg, Glu302 $\rightarrow$ Lys, and Leu435 $\rightarrow$ Arg

Site-directed mutagenesis and/or random mutations have been extensively performed for a number of enzymes, and mutations have been identified that confer desirable properties to the enzymes. When the effects of these mutations are additive, a variant enzyme with multiple mutations would be expected to show more desirable properties. According to a summary of characterization of about 700 variants of phage T4 lysozyme, various kinds of effective stabilizing processes can occur, such as S-S bridges, salt-bridge interactions, metal binding, and hydrophobic stabilization. If the mutated sites are on the molecular surfaces that are not in contact, the stabilizing effects will be additive (Basse et al., 2010). On the other hand, a compromise between activity and stability is generally recognized in various enzymes: mutations that increase enzyme activity also decrease protein stability, while those that increase protein stability decrease enzyme activity (Yutani et al., 1987; Shoichet et al., 1995; Arnorsdottir et al., 2007; Yasukawa and Inouye, 2007; Kusano et al., 2009, 2010). In addition, predicting the effect of mutational combination on 
enzyme properties is not a simple matter.

The relative activity of WT was $1.4 \%$ in the presence of $\mathrm{T} / \mathrm{P}$ (Table 2$)$. The individual mutations, Glu286 $\rightarrow$ Arg, Glu302 $\rightarrow$ Lys, Leu435 $\rightarrow$ Arg, and Asp524 $\rightarrow$ Ala, increased this to $15,24,18$, and $14 \%$, respectively (Table 2 ). When the first three mutations were combined, the relative activity increased to $82 \%$; while combination of all four mutations increased it to $101 \%$ (Table 3), indicating an additive effect of these mutations on stability. On the other hand, the combination of Glu286 $\rightarrow$ Arg, Glu302 $\rightarrow$ Lys, and Leu435 $\rightarrow$ Arg decreased the specific activity to $67-69 \%$ of that of WT, although each individual mutation did not (Table 2). In this case, the stabilizing effects of the mutations were additive, but the combination resulted in a slight decrease in activity.

\section{4. cDNA synthesis by the highly stable multiple variants}

The triple and quadruple variants exhibited cDNA synthesis activity at a highest temperature of $60^{\circ} \mathrm{C}$, which was higher than that seen for WT $\left(54^{\circ} \mathrm{C}\right)$ or D524A $\left(56^{\circ} \mathrm{C}\right)(\mathrm{Fig}$. 5). These variants may therefore be useful for cDNA synthesis reactions. The degree of stability was similar to that reported previously for the stable MMLV RT variant E69K/E302R/W313F/L435G/N454K/D524N (Arezi and Hogrefe, 2009).

We previously examined the effects of organic solvents on cDNA synthesis catalyzed by MMLV RT, and showed that glycerol increased the thermal stability of MMLV RT and AMV RT (Yasukawa et al., 2010b). Like glycerol, the disaccharide trehalose increases the thermal stability of MMLV RT (Carninci et al., 1998). Glycerol and trehalose are widely used in the storage of thermolabile enzymes. However, the theory underlying thermal stabilization by sugars such as glycerol and trehalose has not yet been established. Whether 
glycerol and trehalose can further increase the thermal stabilities of our triple and quadruple variants will be the subject of our next investigations. In regard of this, it was recently reported that the stable MMLV RT variant, E69K/E302R/W313F/L435G/N454K, is highly resistant to common RT-PCR inhibitors including guanidine, thiocyanate, ethanol, formamide, ethylenediaminetetraacetic acid (EDTA), and plant-related acidic polysaccharides (Arezi et al., 2010).

In conclusion, two highly stable MMLV RT variants, E286R/E302K/L435R and E286R/E302K/L435R/D524A, were generated by combining various stabilizing mutations. These multiple variants, as well as others previously reported, might be useful not only for elucidating the structure-function relationship of MMLV RT but also in research and diagnostic applications involving cDNA synthesis and RNA-specific amplification.

\section{Acknowledgments}

This study was supported in part (K. Y.) by Grants-in-Aid for Scientific Research (Nos. 19580104 and 21580110) from the Japan Society for the Promotion of Science and Research for Promoting Technological Seeds (No. 10-038) from Japan Science and Technology Agency.

\section{References}

Aresi, B., Hogrefe, H., 2009. Novel mutations in Moloney murine leukemia virus reverse transcriptase increase thermostability through tighter binding to template-primer. Nucleic Acids Res. 37, 473-481. 
Arezi, B., McCarthy, M., Hogrefe, H., 2010. Mutant Moloney murine leukemia virus reverse transcriptase exhibits higher resistance to common RT-qPCR inhibitors. Anal. Biochem. 400, 301-303.

Arnorsdottir, J., Helgadottir, S., Thorbjarnardottir, S.H., Eggertsson, G., Kristjansson, M.M., 2007. Effect of selected Ser/Ala and Xaa/Pro mutations on the stability and catalytic property of a cold adapted subtilisin-like serine protienase. Biochim. Biophys. Acta $1774,749-755$.

Baase, W.A., Liu, L., Tronrud, D.F., Matthews, B.W., 2010. Lessons from the lysozyme of phage T4. Protein Sci. 19, 631-641.

Baltimore, D., 1970. RNA-dependent DNA polymerase in virions of RNA tumour viruses. Nature 226, 1209-1211.

Berger, S.L., Wallace, D.M., Puskas, R.S., Eschenfiedt, W.H., 1983. Reverse transcriptase and its associated ribonuclease $\mathrm{H}$ : interplay of two enzyme activities controls the yield of single-stranded complementary deoxyribonucleic acid. Biochemistry 22, 2365-2372.

Bieth, E., Darlix, J.-L., 1991. Complete nucleotide sequence of a highly infectious avian leucosis virus. Nucleic Acids Res. 20, 367.

Bradford, M.M., 1976. A rapid and sensitive method for the quantitation of microgram quantities of protein utilizing the principle of protein-dye binding. Anal. Biochem. 72, 248-254.

Carninci, P., Nishiyama, Y., Westover, A., Itoh, M., Nagaoka, S., Sasaki, N., Okazaki, Y., Muramatsu, M., Hayashizaki, Y., 1998. Thermostabilization and thermoactivation of thermolabile enzymes by trehalose and its application for the synthesis of full length cDNA. Proc. Natl. Acad. Sci. USA, 95, 520-524.

Chien, A., Edgar, D.B., Trela, J.M., 1976. Deoxyribonucleic acid polymerase from the 
extreme thermophile Thermus aquaticus. J. Bacteriol. 127, 1550-1557.

Chowdhury, K. Kaushik, N., Pandey, V.N., Modak, M.J., 1996. Elucidation of the role of Arg110 of murine leukemia virus reverse transcriptase in the catalytic mechanism: biochemical characterization of its mutant enzymes. Biochemistry 35, 16610-16620.

Cote, M.L., Roth, M.J., 2008. Murine leukemia virus reverse transcriptase: structural comparison with HIV-1 reverse transcriptase. Virus Res. 134, 186-202.

Das, D., Georgiadis, M.M., 2001. A directed approach to improving the solubility of Moloney murine leukemia virus reverse transcriptase. Protein Sci. 10, 1936-1941.

Das, D., Georgiadis, M.M., 2004. The crystal structure of the monomeric reverse transcriptase from Moloney murine leukemia virus. Structure 12, 819-829.

Georgiadis, M.M., Jessen, S.M., Ogata, C.M., Telesnitsky, A., Goff, S.P., Hendrickson, W.A., 1995. Mechanistic implications from the structure of a catalytic fragment of Moloney murine leukemia virus reverse transcriptase. Structure 3, 879-892.

Gerard, G.F., Potter, R.J., Smith, M.D., Rosenthal, K., Dhariwal, G., Lee, J., Chatterjee, D.K., 2002. The role of template-primer in protection of reverse transcriptase from thermal inactivation. Nucleic Acids Res. 30, 3118-3129.

Ishiguro, T., Saitoh, J., Horie, R., Hayashi, T., Ishizuka, T., Tsuchiya, S., Yasukawa, K., Kido, T., Nakaguchi, Y., Nishibuchi, M., Ueda, K., 2003. Intercalation activating fluorescence DNA probe and its application to homogeneous quantification of a target sequence by isothermal sequence amplification in a closed vessel. Anal. Biochem. 314, 77-86.

Kievits, T., van Gemen, B., van Strijp, D., Schkkink, P., Dircks, M., Adriaanse, H., Malek, L., Sooknanan, R., Lens, P., 1991. NASBA isothermal enzymatic in vitro nucleic acid amplification optimized for the diagnosis of HIV-1 infection. J. Virol. Methods 35, 273-286. 
Khlstaedt, L.A., Wang, J., Friedman, J.M., Rice, P.A., Steitz, T.A., 1992. Crystal structure at $3.5 \AA$ resolution of HIV-1 reverse transcriptase complexed with an inhibitor. Science $256,1783-1790$.

Kimmel, A.R., Berger, S.L., 1987. Preparation of cDNA and the generation of cDNA libraries: overview. Methods Enz. 152, 307-316.

Kusano, M., Yasukawa, K., Inouye, K., 2009. Insights into the catalytic roles the polypeptide regions in the active site of thermolysin and generation of the thermolysin variants with high activity and stability. J. Biochem. 145, 103-113.

Kusano, M., Yasukawa, K., Inouye, K., 2010. Effects of the mutational combinations on the activity and stability of thermolysin. J. Biotechnol. 147, 7-16.

Laemmli, U.K., 1970. Cleavage of structural proteins during the assembly of the head of bacteriophage T4. Nature 227, 680-685.

Lim, D., Gregorio, G.G., Bingman, C., Martinez-Hackert, E., Hendrickson, W.A., Goff, S.P., 2006. Crystal structure of the Moloney murine leukemia virus RNase $\mathrm{H}$ domain. J. Virol. 80, 8379-8389.

Liu, S., Goff, S.P., Gao, G., 2006. Gln84 of moloney murine leukemia virus reverse transcriptase regulates the incorporation rates of ribonucleotides and deoxyribonucleotides. FEBS Lett. 580, 1497-1501.

Masuda, N., Yasukawa, K., Isawa, Y., Horie, R., Saito, J., Ishiguro, T., Nakaguchi, Y., Nishibuchi, M., Hayashi, T., 2004. Rapid detection of $t d h$ and trh mRNAs of Vibrio parahaemolyticus by the transcription-reverse transcription concerted (TRC) method. J. Biosci. Bioeng. 98, 236-243.

Mizuno, M., Yasukawa, K., Inouye, K., 2010. Insight into the mechanism of the stabilization of Moloney murine leukaemia virus reverse transcriptase by eliminating RNase $\mathrm{H}$ 
activity. Biosci. Biotechnol. Biochem. 74, 440-442.

Roberts, J.D., Bebenek, K., Kunkel, T.A., 1988. The accuracy of reverse transcriptase from HIV-1. Science 242, 1171-1173.

Sakoda, M., Hiromi, K., 1976. Determination of the best-fit values of kinetic parameters of the Michaelis-Menten equation by the method of least squares with Taylor expansion. J. Biochem. 80, 547-555.

Shoichet, B.K., Baase, W.A., Kuroki, R., Matthews, B.W., 1995. A relationship between protein stability and protein function. Proc. Natl. Acad. Sci. USA 92, 452-456.

Temin, H.M., Mizutani, S., 1970. RNA-dependent DNA polymerase in virions of Rous sarcoma virus. Nature 226, 1211-1213.

Yasukawa, K., Agata, N., Inouye, K., 2010a. Detection of cesA mRNA from Bacillus cereus by RNA-specific amplification. Enz. Microb. Technol. 46, 391-396.

Yasukawa, K. Inouye, K., 2007. Improving the activity and stability of thermolysin by site-directed mutagenesis. Biochim. Biophys. Acta 1774, 1281-1288.

Yasukawa, K., Konishi, A., Inouye, K., 2010b. Effects of organic solvents on the reverse transcription reaction catalyzed by reverse transcriptases from avian myeloblastosis virus and Moloney murine leukaemia virus. Biosci. Biotechnol. Biochem. in press.

Yasukawa, K., Mizuno, M., Inouye, K., 2009. Characterization of Moloney murine leukaemia virus/avian myeloblastosis virus chimeric reverse transcriptases. J. Biochem. $145,315-324$

Yasukawa, K., Nemoto, D., Inouye, K., 2008. Comparison of the thermal stabilities of reverse transcriptases from avian myeloblastosis virus and Moloney murine leukaemia virus. J. Biochem. 143, 261-268.

Yutani, K., Ogasahara, K., Tsujita, T., Sugino, Y., 1987. Dependence of conformational 
stability on hydrophobicity of the amino acid residue in a series of variant proteins substituted at a unique position of tryptophan synthase $\alpha$ subunit. Proc. Natl. Acad. Sci. USA $84,4441-4444$. 


\section{Figure legends}

Fig. 1. Overall structure of MMLV RT. The structure is based on Protein Data Bank number 1RW3 (Das and Georgiadis, 2004). Peptide chain is displayed by a ribbon model. Residues subject to mutation are displayed by ball and stick. Template-primer (T/P) is schematically shown based on its presumed trajectory exiting the polymerase active site of MMLV RT (Das and Georgiadis, 2004).

Fig. 2. SDS-PAGE of MMLV RT variants under reducing conditions. One $\mu$ g protein was applied to each lane. Coomassie Brilliant Blue-stained 10\% SDS-polyacrlamide gels is shown. (A) Lane 1, molecular-mass marker; lane 2, the wild-type MMLV RT (WT), lane 3, E69A; lane 4, E69K; lane 5, E69R; lane 6, Q84A; lane 7, Q84K; lane 8, Q84R; lane 9, D108A; lane 10, D108K; lane 11, D108R; lane 12, D114A; lane 13, D114K; lane 14, D114R. (B) Lane 1, molecular-mass marker; lane 2, D524A; lane 3, E117A; lane 4, E117K; lane 5, E117R; lane 6, E123A; lane 7, E123K; lane 8, E123R; lane 9, D124A; lane 10, D124K; lane 11, D124R; lane 12, E286A; lane 13, E286K; lane 14, E286R. (C) Lane 1, molecular-mass marker; lane 2, E302A; lane 3, E302K; lane 4, E302R; lane 5, W313A; lane 6, W313K; lane 7, W313R; lane 8, L435A; lane 9, L435K; lane 10, L435R; lane 11, N454A; lane 12, N454K; lane 13, N454R. (D) Lane 1, molecular-mass marker; lane 2, WT; lane 3, D524A; lane 4, E286R/E302K/L435R; lane 5, E286R/E302K/L435R/D524A.

Fig. 3. Dependence on substrate concentration of the initial reaction rate of RT-catalyzed incorporation of dTTP into poly(rA)-p(dT) $)_{15}$ at $37^{\circ} \mathrm{C}$. The initial concentrations of RT and dTTP were $5 \mathrm{nM}$ and $200 \mu \mathrm{M}$, respectively. Solid lines represent the best fit of the 
Michaelis-Menten equation with the non-linear least squares method. Symbols for the enzymes: WT, open circle; D524A, open triangle; E286R/E302K/L435R, closed circle; E286R/E302K/L435R/D524A, closed triangle.

Fig. 4. Irreversible thermal inactivation of MMLV RT. RT at $100 \mathrm{nM}$ was incubated at $48-58^{\circ} \mathrm{C}$ in the presence of poly $(\mathrm{rA})-\mathrm{p}(\mathrm{dT})_{15}(28 \mu \mathrm{M})$ for the indicated durations. Then, the reverse transcription reaction was carried out at $37^{\circ} \mathrm{C}$. The relative activity of RT was defined as the ratio of the initial reaction rate with incubation for the indicated durations to that without incubation [25 nM s${ }^{-1}$ for WT $(5 \mathrm{nM}), 26 \mathrm{nM} \mathrm{s}^{-1}$ for D524A $(5 \mathrm{nM}), 29 \mathrm{nM} \mathrm{s}^{-1}$ for E286R/E302K/L435R (10 nM), and $33 \mathrm{nM} \mathrm{s}^{-1}$ for E286R/E302K/L435R/D524A (10 $\mathrm{nM})$ ]. (A) Thermal inactivation at $52^{\circ} \mathrm{C}$. The first-order rate constant of the thermal inactivation $\left(k_{\mathrm{obs}}\right)$ of RT was estimated from the slope: WT (open circle), $8.3 \times 10^{-3} \mathrm{~s}^{-1}$; D524A (open triangle), $6.0 \times 10^{-3} \mathrm{~s}^{-1}$; E286R/E302K/L435R (closed circle), $4.9 \times 10^{-4} \mathrm{~s}^{-1}$; E286R/E302K/L435R/D524A (closed triangle) $3.0 \times 10^{-4} \mathrm{~s}^{-1}$. (B) Arrhenius plot of $k_{\text {obs }}$ values. The activation energy $\left(E_{\mathrm{a}}\right)$ of thermal inactivation with the $\mathrm{T} / \mathrm{P}$ of $\mathrm{RT}$ was calculated from the slope: WT (open circle), $241 \pm 46 \mathrm{~kJ} \mathrm{~mol}^{-1}$; D524A (open triangle), $279 \pm 15 \mathrm{~kJ}$ $\mathrm{mol}^{-1} ; \quad \mathrm{E} 286 \mathrm{R} / \mathrm{E} 302 \mathrm{~K} / \mathrm{L} 435 \mathrm{R} \quad\left(\right.$ closed circle), $298 \pm 42 \mathrm{~kJ} \mathrm{~mol}^{-1}$; E286R/E302K/L435R/D524A (closed triangle), $322 \pm 22 \mathrm{~kJ} \mathrm{~mol}^{-1}$.

Fig. 5. Dependence on reaction temperature of cDNA synthesis. cDNA synthesis was carried out with $1.6 \mathrm{pg} \operatorname{ces} A$ RNA, $0.2 \mu \mathrm{M}$ RV-R26 primer, and $10 \mathrm{nM}$ RT at $44-64^{\circ} \mathrm{C}$ for 30 min. PCR was carried out with a primer combination of RV and F5. Amplified products were applied to $1 \%$ agarose gel followed by staining with ethidium bromide $(1 \mu \mathrm{g} / \mathrm{ml})$. 
Table 1. Primers.

\begin{tabular}{ll}
\hline Primers & Sequences $\left(5^{\prime}-3^{\prime}\right)$ \\
\hline RV-R26 & TGTGGAATTGTGAGCGGT \\
F5 $^{\mathrm{b}}$ & $\underline{\text { TGCGCGCAAAATGGGTATCAC }}$ \\
RV & TGTGGAATTGTGAGCGG \\
\hline
\end{tabular}

The mismatched nucleotides with the sequence of the wild-type MMLV RT are underlined.

${ }^{a}$ The italicized sequence is identical with that of RV primer, and that underlined corresponds to $9308-9333$ of the sequences deposited in GenBank (DQ360825).

${ }^{b}$ The underlined sequence corresponds to $8725-8745$ of the sequences deposited in GenBank (DQ360825). 
Table 2. Activity and stability of the single variants.

\begin{tabular}{|c|c|c|c|}
\hline & \multirow{2}{*}{$\begin{array}{l}\text { Specific activity }{ }^{\text {a }} \\
\text { (units/mg) }\end{array}$} & \multicolumn{2}{|c|}{ Initial reaction rate $(\mathrm{nM} / \mathrm{s})$} \\
\hline & & Before heat treatment $^{b}$ & $\begin{array}{c}\text { After heat treatment } \\
\text { with } \mathrm{T} / \mathrm{P}^{\mathrm{c}}\end{array}$ \\
\hline WT & $70,000(1.00)^{\mathrm{d}}$ & 41.8 & $0.59(0.014)^{\mathrm{e}}$ \\
\hline D524A & $68,000(0.97)$ & 40.6 & $5.68(0.14)$ \\
\hline E69A & $74,000(1.06)$ & 44.5 & $3.37(0.076)$ \\
\hline E69K & $73,000(1.04)$ & 43.9 & $0.07(0.002)$ \\
\hline E69R & $54,000(0.77)$ & 32.6 & $4.19(0.13)$ \\
\hline Q84A & $84,000(1.20)$ & 50.1 & $0.46(0.009)$ \\
\hline Q84K & $59,000(0.84)$ & 35.1 & $0 \quad(0)$ \\
\hline Q84R & $68,000(0.97)$ & 40.9 & $0.29(0.007)$ \\
\hline D108A & $69,000(0.99)$ & 41.5 & $2.58(0.062)$ \\
\hline D108K & $14,000(0.20)$ & 8.7 & $0.92(0.11)$ \\
\hline D108R & $12,000(0.17)$ & 7.2 & $0.74(0.10)$ \\
\hline D114A & $42,000(0.60)$ & 25.4 & $0.10(0.004)$ \\
\hline $\mathrm{D} 114 \mathrm{~K}$ & $6,000(0.09)$ & 3.3 & $0.01(0.004)$ \\
\hline D114R & $0(0)$ & & \\
\hline E117A & $67,000(0.96)$ & 40.2 & $2.65(0.066)$ \\
\hline E117K & $32,000(0.46)$ & 19.4 & $0.56(0.029)$ \\
\hline E117R & $51,000(0.73)$ & 30.7 & $0.29(0.009)$ \\
\hline E123A & $76,000(1.09)$ & 45.6 & $0.82(0.018)$ \\
\hline E123K & $77,000(1.10)$ & 46.0 & $0.28(0.006)$ \\
\hline E123R & $67,000(0.96)$ & 40.5 & $0.08(0.002)$ \\
\hline D124A & $71,000(1.01)$ & 42.6 & $1.47(0.034)$ \\
\hline D124K & $46,000(0.66)$ & 27.7 & $4.33(0.16)$ \\
\hline D124R & $45,000(0.64)$ & 27.1 & $4.51(0.17)$ \\
\hline E286A & $71,000(1.01)$ & 42.6 & $5.12(0.12)$ \\
\hline E286K & $63,000(0.90)$ & 37.6 & $5.90(0.16)$ \\
\hline E286R & $71,000(1.01)$ & 42.6 & $6.48(0.15)$ \\
\hline E302A & $66,000(0.94)$ & 39.7 & $3.97(0.10)$ \\
\hline E302K & $67,000(0.96)$ & 40.1 & $9.67(0.24)$ \\
\hline E302R & $69,000(0.99)$ & 41.3 & $0.87(0.002)$ \\
\hline W313A & $27,000(0.39)$ & 16.1 & $0.63(0.039)$ \\
\hline W313K & $5,000(0.07)$ & 3.0 & $0.32(0.11)$ \\
\hline W313R & $5,000(0.07)$ & 2.9 & $0.22(0.074)$ \\
\hline L435A & $61,000(0.87)$ & 36.3 & $3.56(0.098)$ \\
\hline L435K & $75,000(1.07)$ & 45.1 & $1.17(0.026)$ \\
\hline L435R & $65,000(0.93)$ & 39.2 & $6.95(0.18)$ \\
\hline N454A & $67,000(0.96)$ & 40.1 & $1.56(0.039)$ \\
\hline N454K & $76,000(1.09)$ & 45.6 & $0.50(0.011)$ \\
\hline N454R & $60,000(0.86)$ & 38.0 & $2.81(0.074)$ \\
\hline
\end{tabular}


The average of triplicate determination is shown for WT and D524A, and that of duplicate determination is shown for the other variants.

${ }^{\mathrm{a}, \mathrm{b}}$ The reaction was carried out in $10 \mathrm{nM}$ RT, $25 \mathrm{mM}$ Tris- $\mathrm{HCl}(\mathrm{pH} 8.3), 50 \mathrm{mM} \mathrm{KCl,} 2 \mathrm{mM}$ DTT, $5 \mathrm{mM} \mathrm{MgCl}_{2}, 25 \mu \mathrm{M}$ poly(rA)-p(dT) $)_{15}$ (this concentration is expressed based on $\mathrm{p}(\mathrm{dT})_{15}$ ), and $0.4 \mathrm{mM}\left[{ }^{3} \mathrm{H}\right] \mathrm{dTTP}$ at $37^{\circ} \mathrm{C}$. One unit is defined as the amount which incorporates $1 \mathrm{nmol}$ of dTTP into poly(rA)-p(dT) $)_{15}$ in $10 \mathrm{~min}$.

${ }^{\mathrm{c}} \mathrm{RT}$ at $100 \mathrm{nM}$ was incubated at $50^{\circ} \mathrm{C}$ in the absence or presence of poly(rA)-p(dT) ${ }_{15}(28$ $\mu \mathrm{M})$ for $15 \mathrm{~min}$. Then, the dTTP incorporation reaction was carried out at $37^{\circ} \mathrm{C}$.

${ }^{\mathrm{d}}$ Numbers in parentheses indicate values relative to WT.

${ }^{\mathrm{e}}$ Numbers in parentheses indicate the relative activity, which is defined as the ratio of the initial reaction rate with incubation to that without incubation. 
Table 3. Activity and stability of the multiple variants.

\begin{tabular}{|c|c|c|c|c|}
\hline & \multirow[b]{2}{*}{$\begin{array}{l}\text { Specific activity } \\
\quad \text { (units/mg) }\end{array}$} & \multicolumn{3}{|c|}{ Initial reaction rate $(\mathrm{nM} / \mathrm{s})$} \\
\hline & & $\begin{array}{l}\text { Before heat } \\
\text { treatment }^{b}\end{array}$ & $\begin{array}{c}\text { After heat } \\
\text { treatment } \\
\text { without } \mathrm{T} / \mathrm{P}^{\mathrm{c}}\end{array}$ & $\begin{array}{l}\text { After heat } \\
\text { treatment } \\
\text { with } \mathrm{T} / \mathrm{P}^{\mathrm{d}}\end{array}$ \\
\hline WT & $70,000 \pm 1,000(1.00)^{\mathrm{e}}$ & $41.8 \pm 0.6$ & $\begin{array}{r}0.08 \pm 0.03 \\
\quad(0.002)^{\mathrm{f}}\end{array}$ & $\begin{array}{l}0.59 \pm 0.38 \\
\quad(0.014)\end{array}$ \\
\hline D524A & $68,000 \pm 9,000(0.97)$ & $40.6 \pm 5.4$ & $\begin{array}{c}1.13 \pm 0.16 \\
(0.028)\end{array}$ & $\begin{array}{l}5.68 \pm 0.41 \\
\quad(0.14)\end{array}$ \\
\hline $\begin{array}{l}\text { E286R/E302K/ } \\
\text { L435R }\end{array}$ & $47,000 \pm 2,000(0.67)$ & $28.1 \pm 1.2$ & $\begin{array}{l}6.74 \pm 0.03 \\
\quad(0.24)\end{array}$ & $\begin{array}{r}23.0 \pm 5.1 \\
(0.82)\end{array}$ \\
\hline $\begin{array}{l}\text { E286R/E302K/ } \\
\text { L435R/D524A }\end{array}$ & $48,000 \pm 6,000(0.69)$ & $28.7 \pm 3.6$ & $\begin{array}{l}9.76 \pm 0.29 \\
(0.34)\end{array}$ & $\begin{array}{c}29.0 \pm 0.3 \\
(1.01)\end{array}$ \\
\hline
\end{tabular}

The average of triplicate determination with SD values is shown.

${ }^{\mathrm{a},} \mathrm{b}$ The experimental condition and the unit definition correspond to those of Table 2 . Molecular masses used for the calculation are 72,161, 72,117, 72,230, and 72,186 Da for WT, D524A, E286R/E302K/L435R, and E286R/E302K/L435R/D524A, respectively.

${ }^{c}$ RT at $100 \mathrm{nM}$ was incubated at $50^{\circ} \mathrm{C}$ in the absence ${ }^{\mathrm{c}}$ or presence ${ }^{\mathrm{d}}$ of poly(rA)-p(dT) $)_{15}(28$ $\mu \mathrm{M})$ for $15 \mathrm{~min}$. Then, the dTTP incorporation reaction was carried out at $37^{\circ} \mathrm{C}$.

${ }^{\mathrm{e}}$ Numbers in parentheses indicate values relative to WT.

${ }^{\mathrm{f}}$ Numbers in parentheses indicate the relative activity, which is defined as the ratio of the initial reaction rate with incubation to that without incubation. 
Table 4. Kinetic parameters of the wild-type MMLV RT and the variants in the reverse transcription reaction at $37^{\circ} \mathrm{C}$.

\begin{tabular}{lccc}
\hline & $K_{\mathrm{m}}(\mu \mathrm{M})$ & $k_{\mathrm{cat}}\left(\mathrm{s}^{-1}\right)$ & $k_{\mathrm{cat}} / K_{\mathrm{m}}\left(\mu \mathrm{M}^{-1} \mathrm{~s}^{-1}\right)$ \\
\hline WT & $8.4 \pm 2.0(1.0)$ & $13.0 \pm 1.2(1.0)$ & $1.5 \pm 0.2(1.0)$ \\
$\mathrm{D} 524 \mathrm{~A}$ & $5.2 \pm 1.2(0.6)$ & $9.2 \pm 0.7(0.7)$ & $1.8 \pm 0.3(1.2)$ \\
$\mathrm{E} 286 \mathrm{R} / \mathrm{E} 302 \mathrm{~K} / \mathrm{L} 435 \mathrm{R}$ & $2.2 \pm 1.1(0.3)$ & $5.6 \pm 0.6(0.4)$ & $2.5 \pm 1.1(1.7)$ \\
$\mathrm{E} 286 \mathrm{R} / \mathrm{E} 302 \mathrm{~K} / \mathrm{L} 435 \mathrm{R} / \mathrm{D} 524 \mathrm{~A}$ & $3.3 \pm 0.7(0.4)$ & $6.6 \pm 0.4(0.5)$ & $2.0 \pm 0.3(1.3)$ \\
\hline
\end{tabular}

The average of triplicate determination with SD values is shown. Numbers in parentheses indicate values relative to WT. 


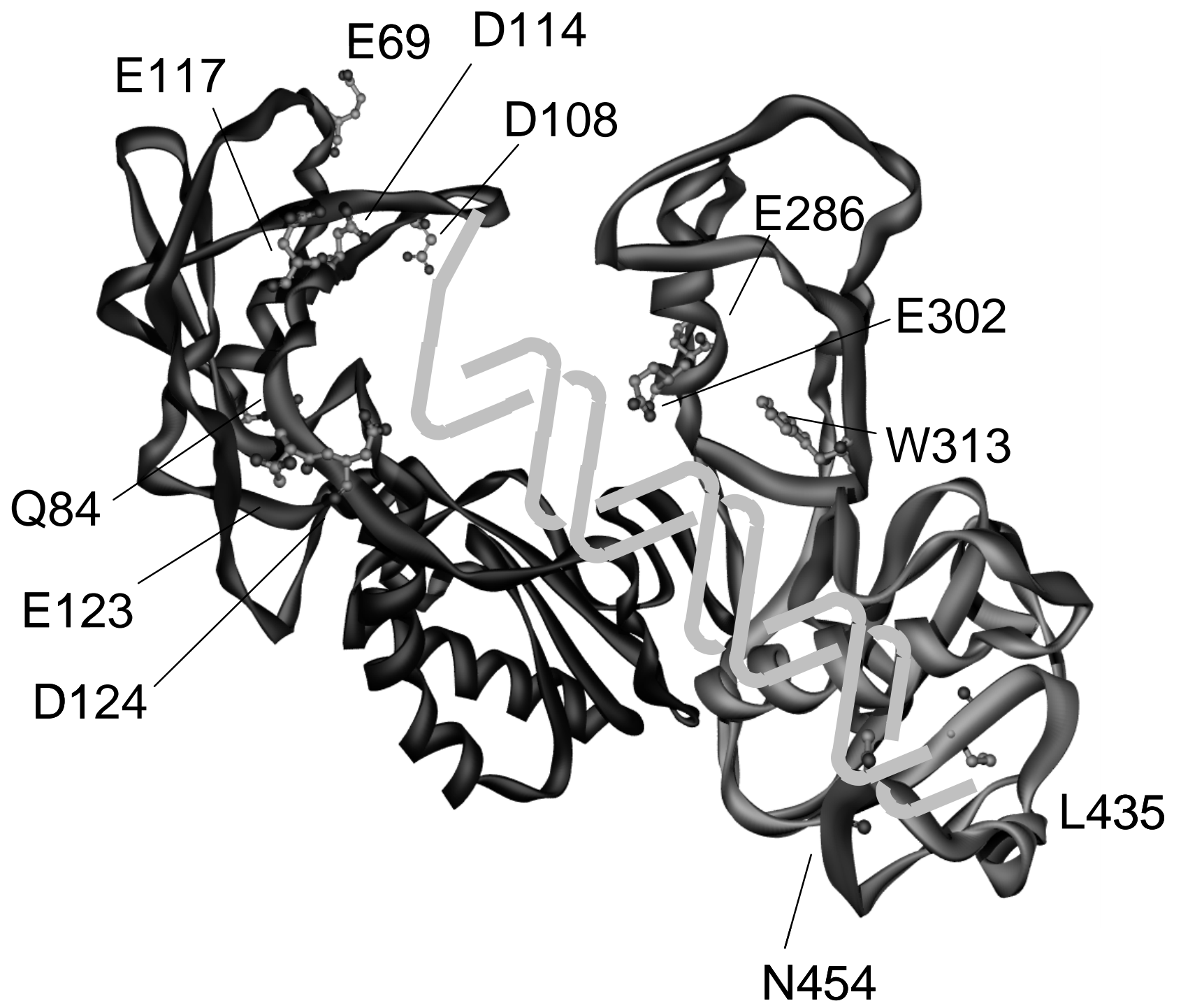

Fig. 1 
A

$$
\begin{array}{llllllllllllll}
1 & 2 & 3 & 4 & 5 & 6 & 7 & 8 & 9 & 10 & 11 & 12 & 13 & 14
\end{array}
$$

$\mathrm{kDa}$

97.2

66.4

44.3

29.0

B

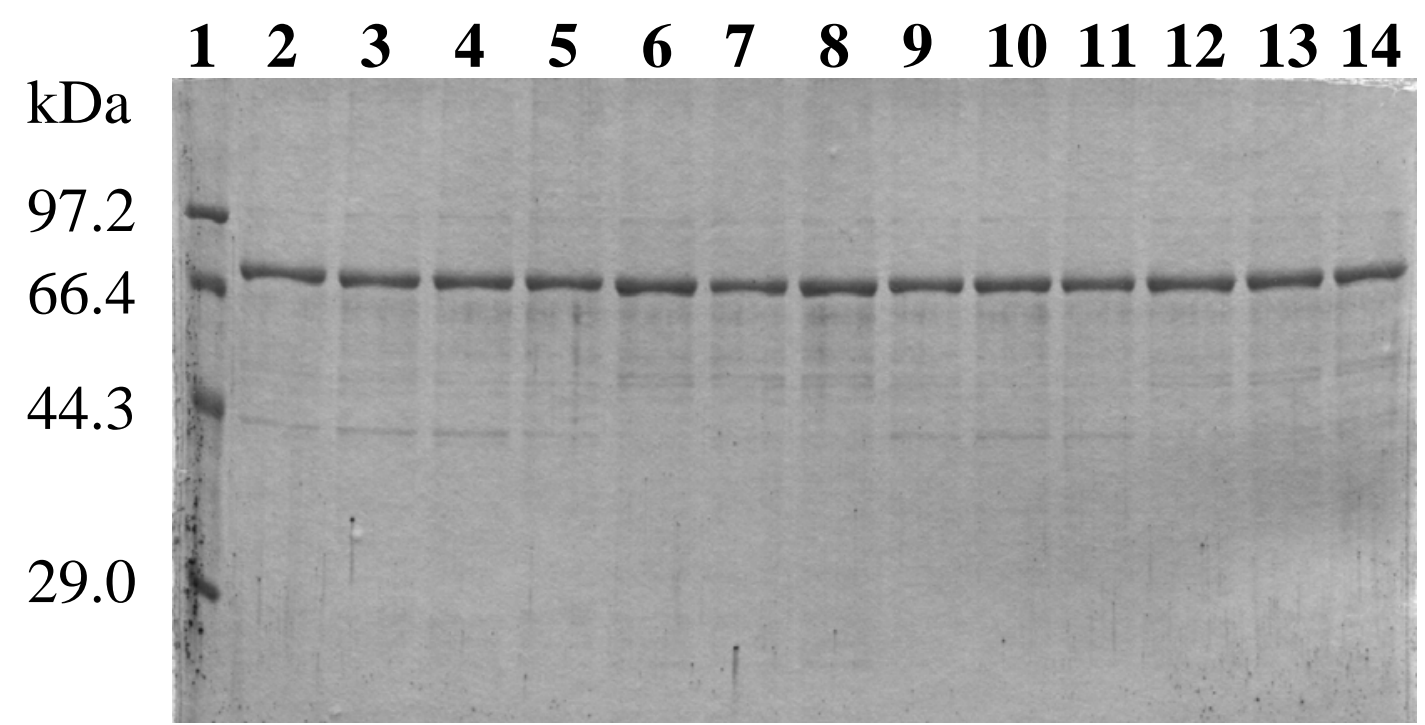

Fig. 2 


\section{$\begin{array}{lllllllllllll}1 & 2 & 3 & 4 & 5 & 6 & 7 & 8 & 9 & 10 & 11 & 12 & 13\end{array}$}

$\mathrm{kDa}$

97.2

66.4

44.3

29.0

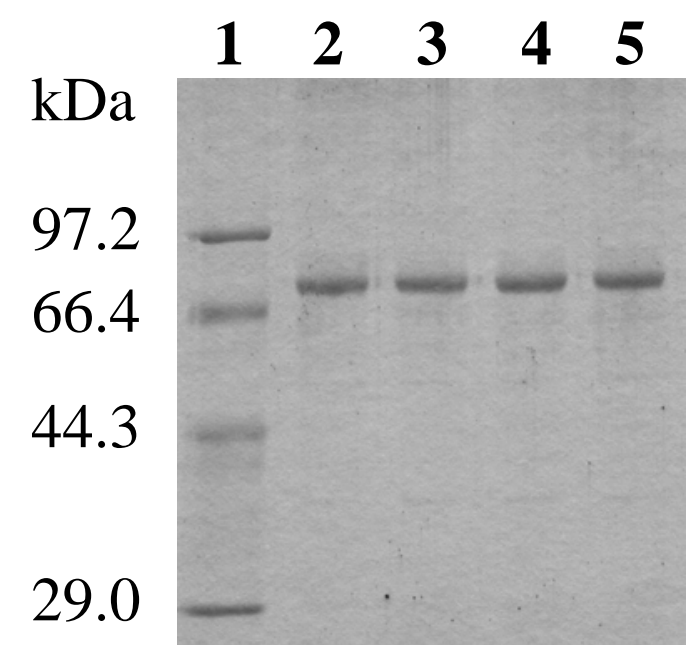

Fig. 2 


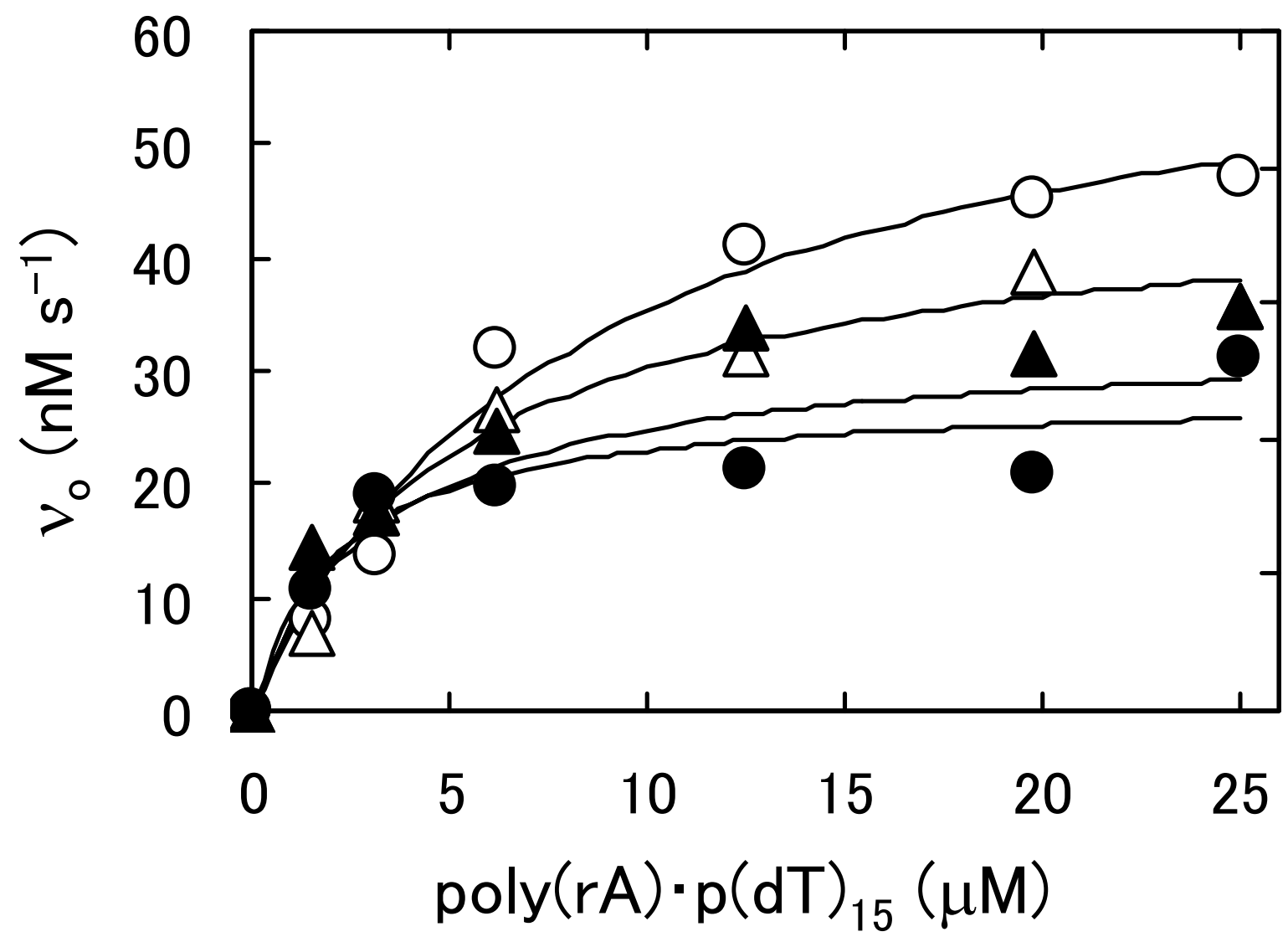

Fig. 3 
A

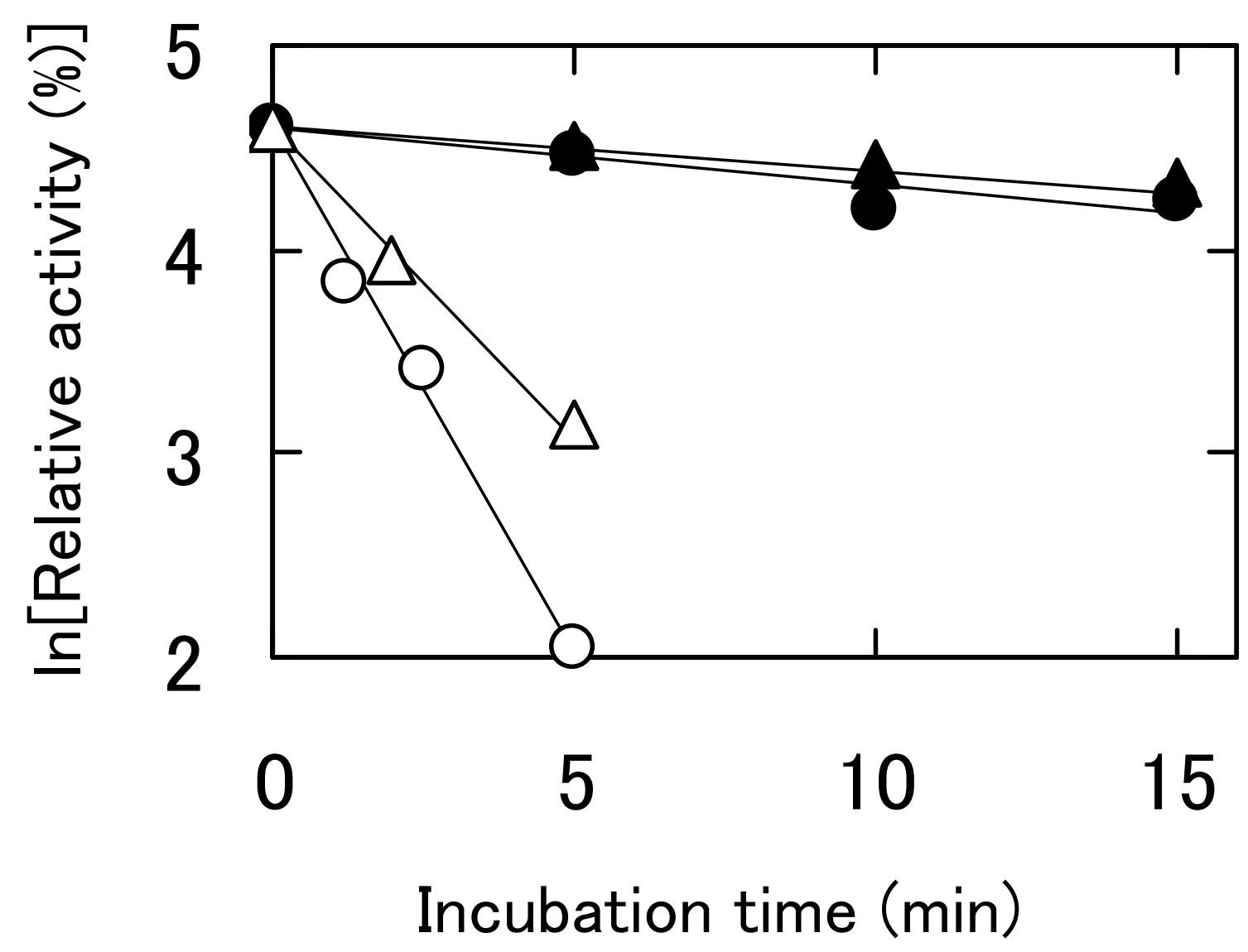

Fig. 4 
B

Temperature $\left({ }^{\circ} \mathrm{C}\right)$

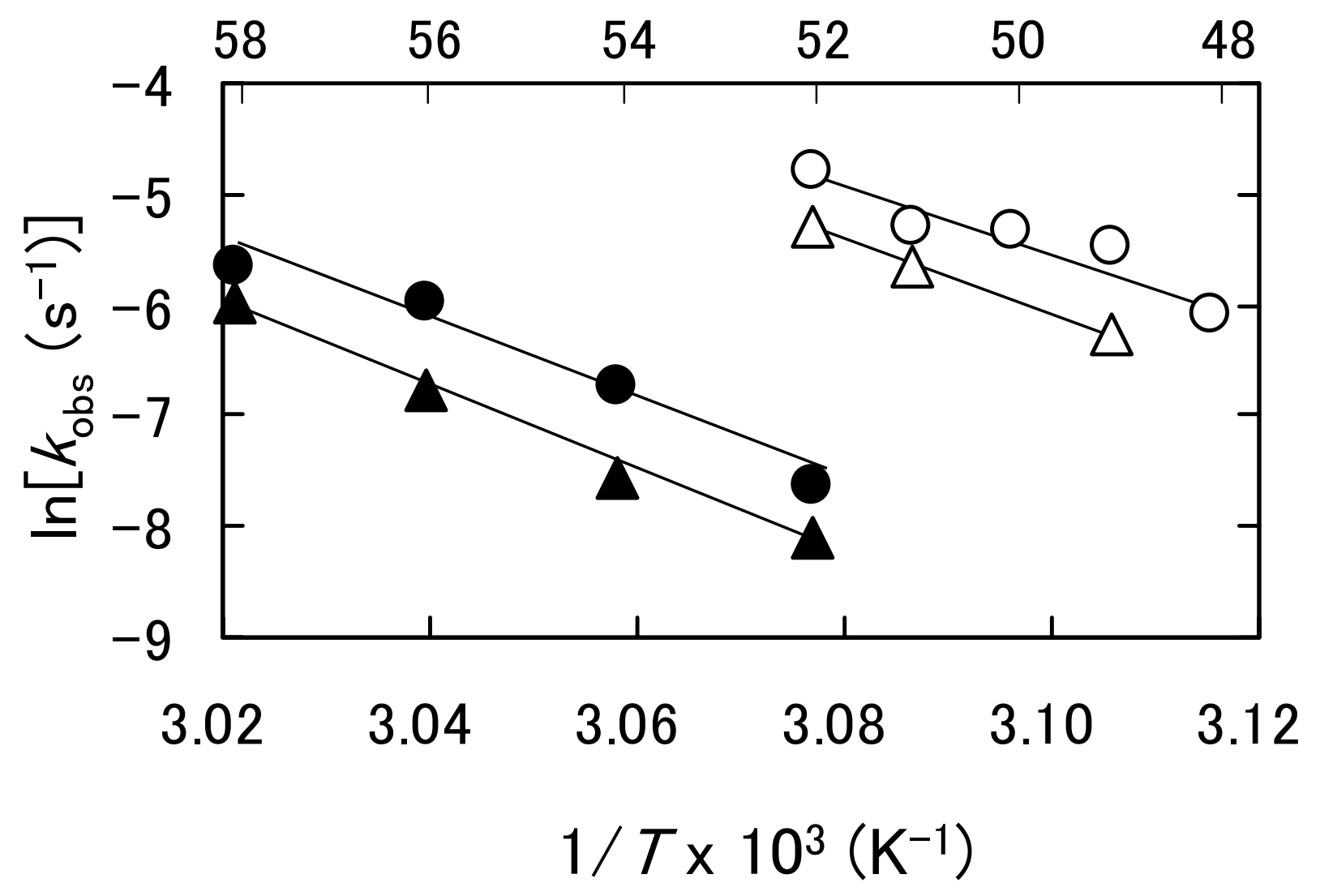

Fig. 4 
Temperature $\left({ }^{\circ} \mathrm{C}\right)$

$\begin{array}{lllllllllll}44 & 46 & 48 & 50 & 52 & 54 & 56 & 58 & 60 & 62 & 64\end{array}$

WT

D524A

E286R/E302K/

$\mathrm{L} 435 \mathrm{R}$

E286R/E302K/

L435R/D524A

Fig. 5 